\title{
Impact of oxidative stress on Acanthamoeba castellanii mitochondrial bioenergetics depends on cell growth stage
}

\author{
Andrzej Woyda-Ploszczyca • Agnieszka Koziel • \\ Nina Antos-Krzeminska • Wieslawa Jarmuszkiewicz
}

Received: 13 December 2010/Accepted: 18 February 2011 /Published online: 27 April 2011

(C) The Author(s) 2011. This article is published with open access at Springerlink.com

\begin{abstract}
Addition of a moderate (1.4 mM) concentration of $\mathrm{H}_{2} \mathrm{O}_{2}$ to protozoon Acanthamoeba castellanii cell cultures at different growth phases caused a different response to oxidative stress. $\mathrm{H}_{2} \mathrm{O}_{2}$ treatment of exponentially growing cells significantly delayed their growth; however, in mitochondria isolated from these cells, no damage to their bioenergetic function was observed. In contrast, addition of $\mathrm{H}_{2} \mathrm{O}_{2}$ to A. castellanii cells approaching the stationary phase did not influence their growth and viability while seriously affecting mitochondrial bioenergetic function. Although mitochondrial integrity was maintained, oxidative damage was revealed in the reduction of cytochrome pathway activity, uncoupling protein activity, and the efficiency of oxidative phosphorylation as well as the membrane potential and the endogenous ubiquinone reduction level of the resting state. An increase in the alternative oxidase protein level and activity as well as an increase in the membranous ubiquinone content were observed in mitochondria isolated from late $\mathrm{H}_{2} \mathrm{O}_{2}$-treated cells. For the first time, the regulation of ubiquinone content in the inner mitochondrial membrane is shown to play a role in the response to oxidative stress. A physiological role for the higher activity of the alternative oxidase in response to oxidative stress in unicellular organisms, such as amoeba $A$. castellanii, is discussed.
\end{abstract}

Andrzej Woyda-Ploszczyca and Agnieszka Koziel contributed equally to this work.

A. Woyda-Ploszczyca $\cdot$ A. Koziel $\cdot$ N. Antos-Krzeminska $\cdot$

W. Jarmuszkiewicz $(\square)$

Department of Bioenergetics, Institute of Molecular Biology

and Biotechnology, Adam Mickiewicz University,

Umultowska 89,

61-614 Poznan, Poland

e-mail: wiesiaj@amu.edu.pl
Keywords Acanthamoeba castellanii . Alternative oxidase $\cdot$ Hydrogen peroxide Oxidative stress . Mitochondria $\cdot$ Ubiquinone $\cdot$ Uncoupling protein

\begin{tabular}{|c|c|}
\hline \multicolumn{2}{|c|}{ Abbreviations } \\
\hline AcAOX & $\begin{array}{l}\text { Alternative oxidase of Acanthamoeba } \\
\text { castellanii }\end{array}$ \\
\hline AcUCP & $\begin{array}{l}\text { Uncoupling protein of Acanthamoeba } \\
\text { castellanii }\end{array}$ \\
\hline $\mathrm{AOX}$ & Alternative oxidase \\
\hline BHAM & Benzohydroxamate \\
\hline BSA & Bovine serum albumin \\
\hline COX & Cytochrome $c$ oxidase \\
\hline$\Delta \mu \mathrm{H}^{+}$ & Proton electrochemical gradient \\
\hline FCCP & $\begin{array}{l}\text { Carbonyl cyanide } p \text {-trifluoromethoxyphe- } \\
\text { nylhydrazone }\end{array}$ \\
\hline ROS & Reactive oxygen species \\
\hline state 3 & $\begin{array}{l}\text { Phosphorylating respiration (in the presence } \\
\text { of ADP) }\end{array}$ \\
\hline state 4 & $\begin{array}{l}\text { Resting respiration (in the absence of added } \\
\text { ADP) }\end{array}$ \\
\hline $\mathrm{RCR}$ & Respiratory control ratio (state 3/state 4 ) \\
\hline TMPD & $\mathrm{N}, \mathrm{N}, \mathrm{N}^{\prime} \mathrm{N}^{\prime}$-tetramethyl- $p$-phenylenediamine \\
\hline UCP & Uncoupling protein \\
\hline Q & Ubiquinone (coenzyme Q) \\
\hline $\mathrm{QH}_{2}$ & Reduced Q (ubiquinol) \\
\hline Qtot & $\begin{array}{l}\text { Total pool of endogenous } Q \text { in the inner } \\
\text { mitochondrial membrane }\end{array}$ \\
\hline $\mathrm{QH}_{2} / \mathrm{Qtot}$ & Reduction level of Q \\
\hline
\end{tabular}

Introduction

Mitochondria are the key cellular source of superoxide $\left(\mathrm{O}_{2}{ }^{-}\right)$and hydrogen peroxide $\left(\mathrm{H}_{2} \mathrm{O}_{2}\right)$. The oxidative stress 
resulting from an increase in the generation of reactive oxygen species (ROS) leads to damage of mitochondrial DNA, proteins, membranes, acceleration of aging, and in many cases, to cell death (Papa and Skulachev 1997). Hydrogen peroxide is damaging to mitochondria and other cell components because it can oxidize biomolecules directly or through the formation of hydroxyl radical. The consequences of elevated mitochondrial $\mathrm{H}_{2} \mathrm{O}_{2}$ concentrations include protein and lipid peroxidation, cytochrome $c$ release, inactivation of respiratory chain carriers and other mitochondrial enzymes, and uncoupling or decrease in respiration (Vladimirov et al. 1980; Zhang et al. 1990; Radi et al. 1993; Sweetlove et al. 2002).

Acanthamoeba castellanii is a small, non-photosynthesizing free-living amoeba found in soil and water environments. A. castellanii is also an opportunistic pathogen of clinical interest that is responsible for several distinct human diseases. In molecular phylogenesis, A. castellanii appears on a branch basal to the divergence points of plants, animals, and fungi (Wainright et al. 1993). Under axenic non-pathogenic conditions, $A$. castellanii has been used as a model organism to study mitochondrial energydissipating systems, such as a cyanide-resistant alternative oxidase (AcAOX) (Jarmuszkiewicz et al. 2005a; Woyda-Ploszczyca et al. 2009), an ATP-sensitive potassium channel (Kicinska et al. 2007), and an uncoupling protein (AcUCP) (Jarmuszkiewicz et al. 2010). The mitochondria of $A$. castellanii contain a plant-type respiratory chain with additional (in addition to the four classical) electron carriers in the form of external and internal $\mathrm{NADH}$ dehydrogenases and an alternative cyanide-resistant quinol oxidase (AOX) that consumes mitochondrial reducing power without energy conservation in the proton electrochemical gradient (Jarmuszkiewicz et al. 1997). We have shown that in A. castellanii, as in plant mitochondria (Popov 2003; Vercesi et al. 2006), the two mitochondrial energy-dissipating systems, AcAOX and AcUCP, may play a role in the energetic status of the cell by decreasing the yield of ATP synthesis and in attenuating ROS production (Czarna and Jarmuszkiewicz 2005; Czarna et al. 2007). Moreover, the contribution of both energy-dissipating systems in the prevention of mitochondrial ROS generation in vivo could ensure their constant level throughout the growth cycle of the $A$. castellanii batch culture (Czarna et al. 2007). It has been shown that both AcUCP and AcAOX could be cold response proteins in unicellular organisms because cold treatment of amoeba cultures increases their activity and protein level (Jarmuszkiewicz et al. 2001, 2004).

We have observed previously that short $(5 \mathrm{~min})$ incubation of isolated A. castellanii mitochondria with $\mathrm{H}_{2} \mathrm{O}_{2}$ (up to $25 \mathrm{mM}$ ) did not significantly damage their basic energetics (Jarmuszkiewicz et al. 2008). In the present study, cell cultures were treated with $\mathrm{H}_{2} \mathrm{O}_{2}$. to overcome the remarkable resistance of $A$. castellanii mitochondria to oxidative damage. The aim of the present work was to establish a response of $A$. castellanii mitochondria to oxidative stress caused by $\mathrm{H}_{2} \mathrm{O}_{2}$ added to cell batch cultures at different phases of growth, i.e., during intensive cells division at inoculation (at the exponential phase of growth) and during slowing cell division as the stationary phase of growth is approached. We measured changes in mitochondrial bioenergetics, including mitochondrial respiration through the energy-conserving (the cytochrome pathway) and energy-dissipating (the AcUCP-sustained respiration and AcAOX-mediated respiration) systems, the efficiency of oxidative phosphorylation, and outer mitochondrial membrane integrity.

\section{Materials and methods}

Cell culture and mitochondrial isolation

The soil amoeba Acanthamoeba castellanii, strain Neff, was cultured as described previously (Czarna et al. 2007). After $72 \mathrm{~h}$, cells were inoculated (time 0 ) to a final density of approximately $3.5 \pm 0.2 \times 10^{5} \mathrm{cell} / \mathrm{ml}$ (Fig. 1). After about $40 \mathrm{~h}$ of exponential growth with a generation time (a cell doubling time) of 7-8 $\mathrm{h}$, amoeba cultures reach the intermediary phase and then the stationary phase, and the latter stage precedes transformation into cysts within a few hours. Cell cultures were treated with $1.4 \mathrm{mM} \mathrm{H}_{2} \mathrm{O}_{2}$ added once at $48 \mathrm{~h}$ following inoculation (late $\mathrm{H}_{2} \mathrm{O}_{2}$-treated cells)

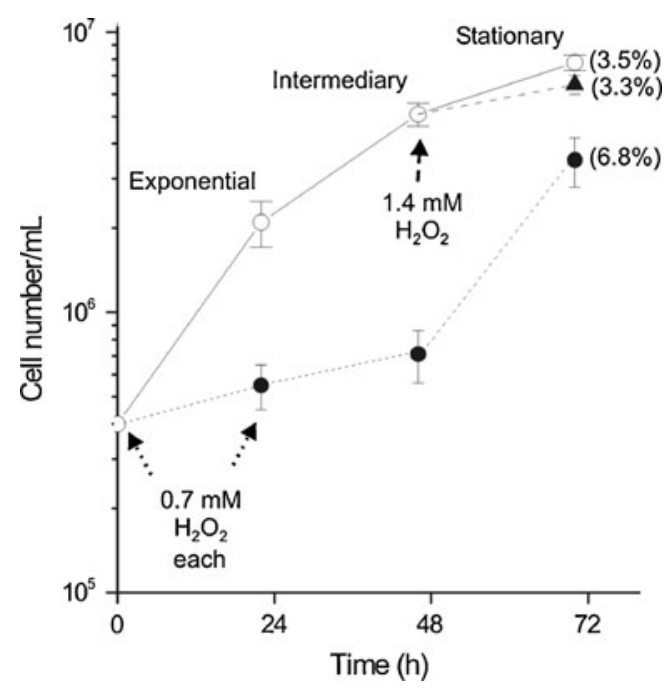

Fig. 1 Growth of A. castellanii cells in agitated batch cultures at $28^{\circ}$ C. Cell numbers were determined at the specified intervals. Mean values $( \pm \mathrm{SE})$ from three separate experiments are shown. Additions of $\mathrm{H}_{2} \mathrm{O}_{2}$ are indicated. The percentage of dead cells in the $A$. castellanii batch culture is shown in brackets 
or in two portions of $0.7 \mathrm{mM} \mathrm{H}_{2} \mathrm{O}_{2}$ added first at inoculation and then at $24 \mathrm{~h}$ following inoculation (early $\mathrm{H}_{2} \mathrm{O}_{2}$-treated cells) (Fig. 1). Trophozoites of $A$. castellanii were harvested from cultures at $72 \mathrm{~h}$ following inoculation at the following densities: control untreated cells, $7.8 \pm 0.7 \times 10^{6}$ cell $/ \mathrm{ml}$; late $\mathrm{H}_{2} \mathrm{O}_{2}$-treated cells, $6.5 \pm 0.8 \times 10^{6}$ cells $/ \mathrm{ml}$; and early $\mathrm{H}_{2} \mathrm{O}_{2}$-treated cells, $3.5 \pm 0.4 \times 10^{6} \mathrm{cell} / \mathrm{ml}$.

Mitochondria were isolated by differential centrifugation and purified on a self-generating Percoll gradient (30\%) as described previously (Jarmuszkiewicz et al. 1997). The depletion of endogenous free fatty acids in the mitochondrial preparations was ensured by the presence of $0.4 \%$ fatty acidfree bovine serum albumin (BSA) in the isolation media except for the last mitochondrial washing (Jarmuszkiewicz et al. 1999). The mitochondrial protein concentration was determined using the biuret method using BSA as a standard.

Cell viability

A. castellanii cells were incubated at a $1: 1$ ratio with $0.05 \%$ $(w / v)$ Evans blue solution. After addition of the dye, the cells were incubated $15 \mathrm{~min}$ at $25^{\circ} \mathrm{C}$ and then placed on a counting chamber (hemocytometer). Observations were made using a normal, transmitted light microscope (Carl Zeiss, Germany), and the counts of blue-stained versus nonstained bright-yellowish cells were scored separately.

\section{Oxygen uptake}

Oxygen uptake was measured polarographically using a Rank Bros. (Cambridge, UK) oxygen electrode or a Hansatech oxygen electrode with $1 \mathrm{mM}$ NADH, $7 \mathrm{mM}$ succinate or $7 \mathrm{mM}$ malate as respiratory substrates in $3 \mathrm{ml}$ or $1.5 \mathrm{ml}$, respectively, of the standard reaction medium $\left(25^{\circ} \mathrm{C}\right)$ containing $120 \mathrm{mM} \mathrm{KCl}, 20 \mathrm{mM}$ Tris- $\mathrm{HCl}, \mathrm{pH} 7.4$, $3 \mathrm{mM} \mathrm{KH}_{2} \mathrm{PO}_{4}, 2 \mathrm{mM} \mathrm{MgCl}_{2}$, plus or minus $0.1 \% \mathrm{BSA}$ (fatty acid free), and 3 or $1.5 \mathrm{mg}$ of mitochondrial protein to maintain a concentration of $1 \mathrm{mg} \times \mathrm{ml}^{-1}$. Values for $\mathrm{O}_{2}$ uptake are presented in $\mathrm{nmolO} \times \mathrm{min}^{-1} \times \mathrm{mg}^{-1}$ protein.

State 3 measurements were performed in the presence of $2 \mathrm{mM}$ or $200 \mu \mathrm{M}$ (pulse) ADP. For ADP/O ratio calculations, the total amount of oxygen consumed during pulse state 3 respiration was used. To inhibit the AcAOX and cytochrome pathway activities, $2 \mathrm{mM}$ benzoxydroxamate (BHAM) and $1.5 \mathrm{mM}$ cyanide, respectively, were used. The AcUCP activity was inhibited with $2 \mathrm{mM}$ GTP. To activate AcAOX, $1 \mathrm{mM}$ GMP was supplied. Different concentrations (up to $20 \mu \mathrm{M}$ ) of linoleic acid, which is the most efficient activator of AcUCP (Swida et al. 2007), were used to activate AcUCP and thereby the UCP activitysustained respiration. To exclude the activity of the ATP/ ADP antiporter, $1 \mu \mathrm{M}$ carboxyatractyloside was used in state 4 measurements.
The cytochrome $c$ oxidase (COX) maximal activity was assessed with $0.25 \mathrm{mg}$ of mitochondrial protein without exogenously added respiratory substrate and in the presence of antimycin A (4 $\mu \mathrm{g} / \mathrm{mg}$ of mitochondrial protein), $8 \mathrm{mM}$ ascorbate, $0.06 \%$ cytochrome $c$, and up to $2.5 \mathrm{mM} \mathrm{N}, \mathrm{N}, \mathrm{N}^{\prime}$ $\mathrm{N}^{\prime}$-tetramethyl-p-phenylenediamine (TMPD). The rate of oxygen consumption following the addition of TMPD reflected the maximal $\mathrm{O}_{2}$ consumption by $\mathrm{COX}$ (complex IV). Outer mitochondrial membrane integrity was assayed as the latency of COX activity during the same measurements, i.e., the acceleration of respiration by addition of cytochrome $c$ prior to addition of TMPD.

\section{Membrane potential}

The membrane potential $(\Delta \Psi)$ of the mitochondria was measured simultaneously with the oxygen uptake using a tetraphenylphosphonium-specific electrode according to Kamo et al. (1979). To calculate the $\Delta \Psi$ value the matrix volume of amoeba mitochondria was assumed for $2.0 \mu \mathrm{l}$ $\mathrm{mg}^{-1}$ protein. The calculation assumes that $\mathrm{TPP}^{+}$distribution between the mitochondria and the medium followed the Nernst equation. $\Delta \Psi$ values are presented in $\mathrm{mV}$.

\section{Determination of the amount of ubiquinone}

The endogenous pool of ubiquinone (Q) in the inner mitochondrial membrane was determined by an extraction technique (from 1 to $2 \mathrm{mg}$ of mitochondrial protein), followed by HPLC detection (Czarna et al. 2007). The endogenous ubiquinone in $A$. castellanii mitochondria is Q-9 (Jarmuszkiewicz et al. 1998). For peak calibration, commercial Q-9 (Sigma) was used. Q reduction levels are expressed as a percentage of total $\mathrm{Q}\left(\mathrm{QH}_{2} / \mathrm{Qtot}\right)$.

\section{SDS-PAGE and immunoblotting}

Up to $200 \mu \mathrm{g}$ of mitochondrial protein (stored in $-80{ }^{\circ} \mathrm{C}$ ) was solubilized in the sample buffer containing $2 \%(w / v)$ SDS, $80 \mathrm{mM}$ Tris- $\mathrm{HCl}$ ( $\mathrm{pH}$ 6.8), 10\% glycerol, $0.04 \%(\mathrm{~m} / \mathrm{v})$ bromophenol blue and 2-5\% mercaptoethanol (for AcAOX detection, $40 \mathrm{mM}$ DTT was added) and boiled for $5 \mathrm{~min}$. Electrophoresis (SDS-PAGE) was carried out using a 5\% polyacrylamide stacking gel and a $12-16 \%$ polyacrylamide resolving gel with $4.5 \mathrm{M}$ urea followed by Western blotting. Prestained low-molecular-weight markers were used. Antibodies against AOX of $S$. guttatum (generously supplied by Dr. T.E. Elthon) were used at dilutions of 1:1000. Antibodies raised against UCP3 of human skeletal muscle (Alpha Diagnostic, UCP34-A) were used at dilutions of 1:500. Antibodies against subunit III of yeast cytochrome $c$ oxidase (COX III, Molecular Probes, A6408) were used at dilutions of 1:1000. Protein bands were visualized using the Amersham 
ECL system and quantified digitally. Detection of COX III, which was present as a constant amount throughout culture growth, is considered to be the loading control for detection of the other proteins.

\section{Protein carbonyl assay}

Carbonylated proteins were analyzed using the oxyblot kit according to the manufacturer's instructions (Oxyblot, Millipore). Briefly, mitochondrial samples (10 $\mu \mathrm{g}$ per lane $)$ were treated with $10 \mathrm{mM}$ 2,4-dinitrophenolohydrazine in $2 \mathrm{M} \mathrm{HCl}$, incubated at room temperature and neutralized. The derivatized proteins were separated using SDS-PAGE, transferred to a nitrocellulose membrane and treated as previously described for Western blotting (see above). The primary antibody used was against 2,4-dinitrophenol, and detection was performed using the $\mathrm{ECl}$ reagent.

\section{Chemicals}

Hydrogen peroxide (Sigma, INFARM) concentrations were determined using a molar absorption coefficient of $43.6 \mathrm{M}^{-1} \mathrm{~cm}^{-1}$ at $240 \mathrm{~nm}$.

\section{Results}

Growth condition of $A$. castellanii batch culture

The principal objective of the present study was to describe the response of $A$. castellanii mitochondria to oxidative stress caused by $\mathrm{H}_{2} \mathrm{O}_{2}$ added to batch cultures at different phases of growth, i.e., during intensive cell division and during slowing cell division as the stationary phase is approached preceding encystment. A total concentration of $1.4 \mathrm{mM} \mathrm{H}_{2} \mathrm{O}_{2}$ was chosen because higher concentrations (above $2 \mathrm{mM}$ ) led to the complete inhibition of $A$. castellanii cell growth and severe cell damage, from which isolation of mitochondria was impossible. Therefore, separate two additions of $0.7 \mathrm{mM} \mathrm{H}_{2} \mathrm{O}_{2}$ at inoculation and at the exponential phase (early $\mathrm{H}_{2} \mathrm{O}_{2}$-treated cells) or a single addition of $1.4 \mathrm{mM} \mathrm{H} \mathrm{H}_{2}$ at the intermediary phase (late $\mathrm{H}_{2} \mathrm{O}_{2}$-treated cells) were performed (Fig. 1). In the case of early $\mathrm{H}_{2} \mathrm{O}_{2}$-treated cells, a significant delay in the growth of the $A$. castellanii batch culture was observed until $48 \mathrm{~h}$ following inoculation. After this period, cells restarted intensive division and reached the density of a late exponential phase of growth $\left(\sim 3.5 \pm 0.4 \times 10^{6} \mathrm{cell} / \mathrm{ml}\right)$. The percentage content of dead cells when trophozoites were harvested for isolation of the mitochondria (at $72 \mathrm{~h}$ following inoculation) was approximately double that of the control cells. Addition of $\mathrm{H}_{2} \mathrm{O}_{2}$ at the intermediary phase (late $\mathrm{H}_{2} \mathrm{O}_{2}$-treated cells) did not considerably

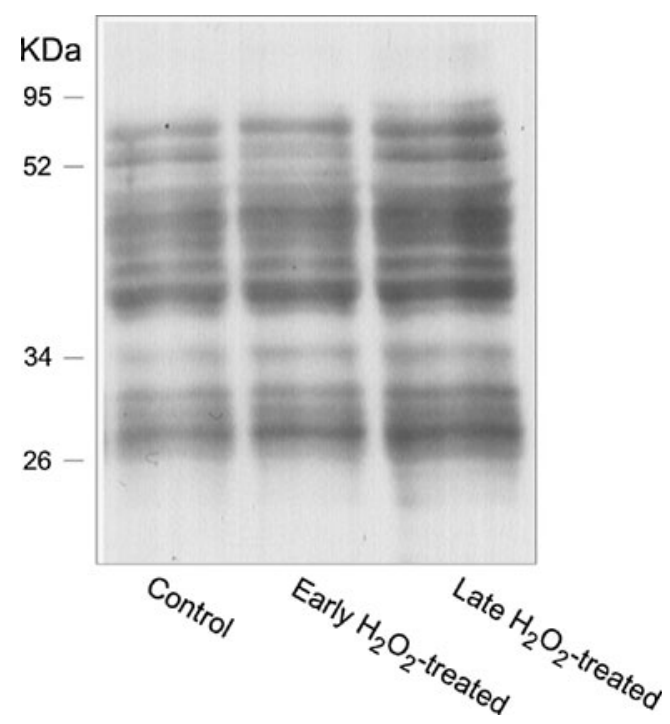

Fig. 2 Levels of oxidized proteins in mitochondria isolated from $A$. castellanii cultures grown in the absence (control cells) or presence of $\mathrm{H}_{2} \mathrm{O}_{2}$ (early and late $\mathrm{H}_{2} \mathrm{O}_{2}$-treated cells). Examples of three oxyblots using mitochondria from different preparations are shown. The mitochondrial protein equivalent of $40 \mu \mathrm{g}$ was loaded in all lines. The gel was stained with oxyblot kit

influence the growth of the batch culture or the amount of dead cells.

To evaluate whether $\mathrm{H}_{2} \mathrm{O}_{2}$ treatment of the $A$. castellanii culture influences the level of oxidized proteins in the mitochondria, we examined the isolated mitochondria for protein byproducts modified by oxidative damage (Fig. 2). Analysis of the mitochondria lysates revealed significantly elevated levels of protein carbonyls, which is a general marker of oxidative damage, in mitochondria isolated from late $\mathrm{H}_{2} \mathrm{O}_{2}$-treated cells relative to the control cells. In mitochondria isolated from early $\mathrm{H}_{2} \mathrm{O}_{2}$-treated cells, no increase or a slight increase in oxidized proteins was observed, indicating that the $24 \mathrm{~h}$ regeneration period of intensive cell division following $48 \mathrm{~h}$ of $\mathrm{H}_{2} \mathrm{O}_{2}$-induced stress led to elimination or reduction of oxidative damage caused by $\mathrm{H}_{2} \mathrm{O}_{2}$.

Fig. 3 Cytochrome pathway capacity in mitochondria isolated from A. castellanii cultures grown in the presence of $\mathrm{H}_{2} \mathrm{O}_{2}$ during intensive cell devision (early $\mathrm{H}_{2} \mathrm{O}_{2}$-treated cells) and during slowing cell division (late $\mathrm{H}_{2} \mathrm{O}_{2}$-treated cells). a For uncoupled respiration measurements with $1 \mu \mathrm{M}$ FCCP, $0.1 \%$ BSA, 2 mM BHAM, $0.5 \mu \mathrm{M}$ oligomycin, $1 \mu \mathrm{M}$ carboxyatractyloside, and either $1 \mathrm{mM}$ NADH (plus $4 \mu \mathrm{M}$ rotenone), $7 \mathrm{mM}$ succinate $(4 \mu \mathrm{M}$ rotenone) or $7 \mathrm{mM}$ malate were supplied. b, c. Coupling parameters were obtained when state 3 measurements were performed with $200 \mu \mathrm{M}$ ADP pulses in the presence of $0.1 \%$ BSA, $2 \mathrm{mM}$ BHAM, and $1 \mathrm{mM} \mathrm{NADH}$ as a respiratory substrate. RCR refers to respiratory control ratios. d COX capacity measurements. e and $\mathbf{f}$ Membrane potential and $\mathrm{Q}$ reduction level of resting (non-phosphorylating) mitochondria oxidizing NADH. g Changes in the amount of total ubiquinone (Q9). The data are the mean $( \pm \mathrm{SE})$ of five different mitochondrial preparations $(n=9-10) .{ }^{*}$, ** Where indicated, $p$ values are significantly different from control values ( $p<0.05$ or $p<0.01$, respectively; Student's unpaired $t$ test) 
A.
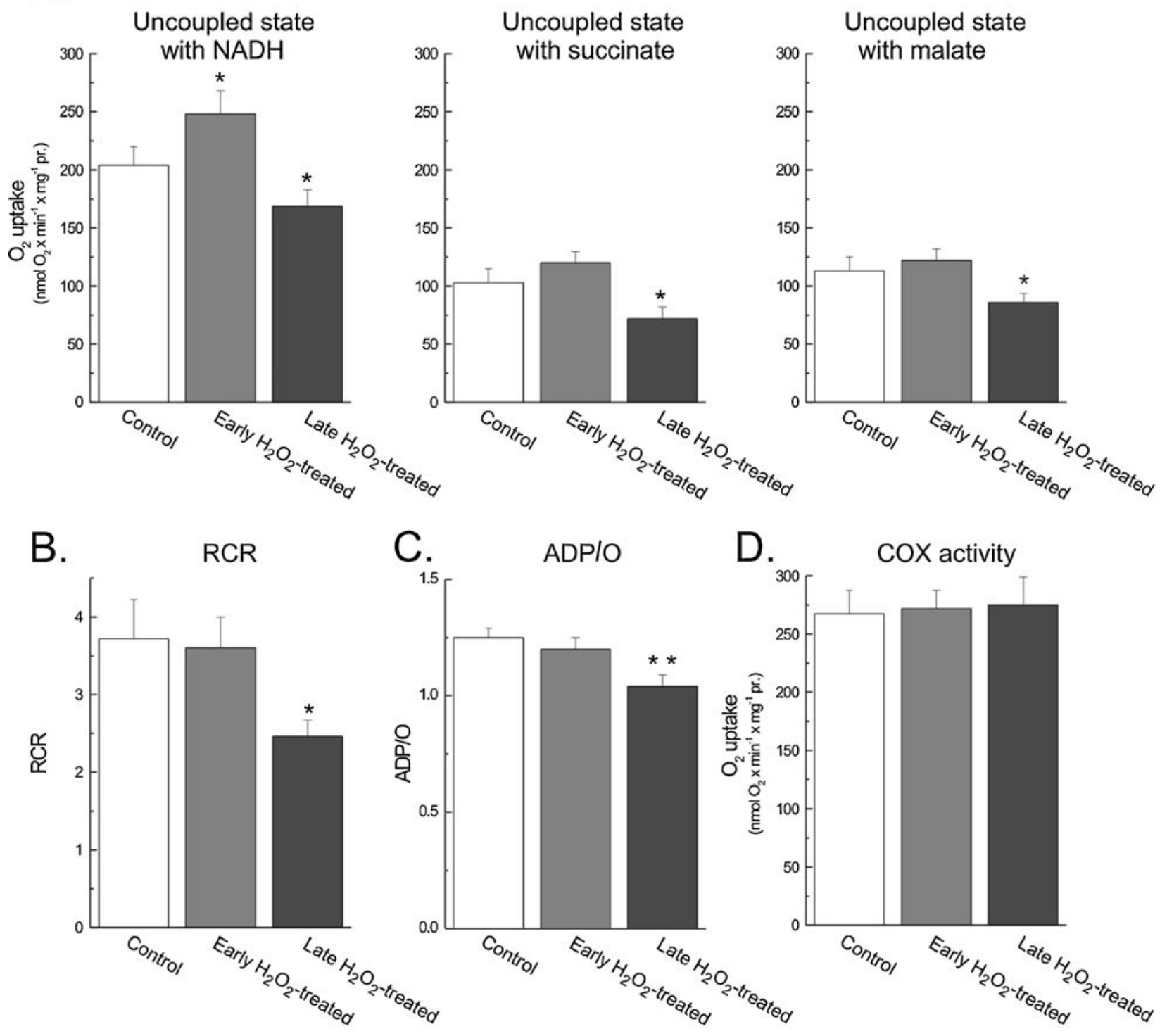

C. ADP/O

D.

COX activity

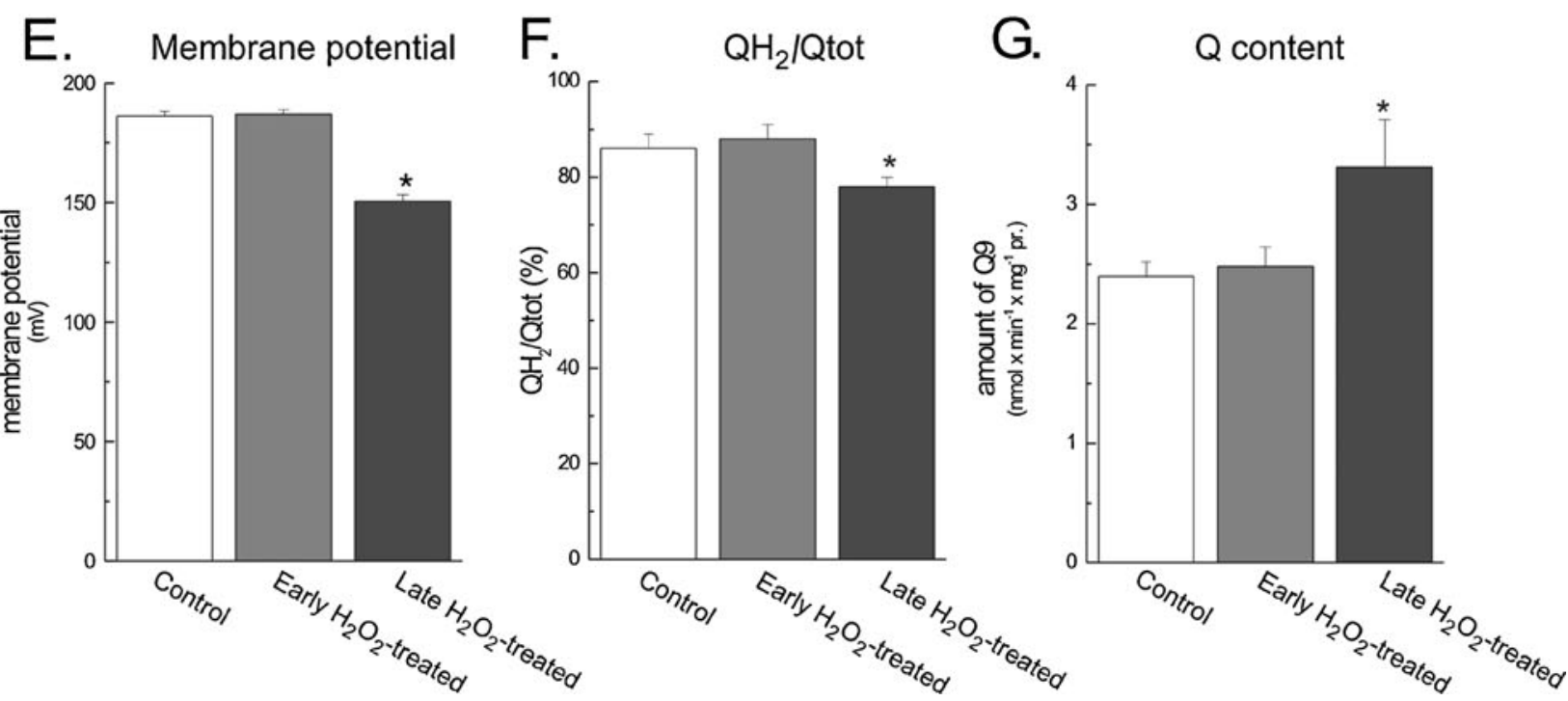


Cytochrome pathway components and capacity

The capacity for cytochrome pathway-dependent respiration was measured in the presence of $1 \mu \mathrm{M}$ FCCP (an uncoupler). To exclude the activity of AcAOX and AcUCP, measurements were carried out in the presence of BHAM, which is an inhibitor of AOX, and BSA, which chelates free fatty acids. The results obtained with external NADH (plus rotenone), succinate (plus rotenone) or malate as respiratory substrates are shown in Fig. 3a. Coupling parameters, i.e., the respiratory control ratio ( $\mathrm{RCR}$ ) and $\mathrm{ADP} / \mathrm{O}$ as well as the membrane potential of resting (non-phosphorylating) mitochondria were measured with external NADH (Fig. 3b-d). External NADH was chosen instead of complex I or complex II substrates to avoid limitations on the cytochrome pathway capacity by these two complexes (Jarmuszkiewicz et al. 2002; Czarna et al. 2007). Additionally, the activity of cytochrome $c$ oxidase (complex IV) and the amount of total membranous ubiquinone (Q) were measured (Fig. 3e, f).

In the A. castellanii mitochondria isolated from cultures grown in the presence of two portions of $0.7 \mathrm{mM} \mathrm{H}_{2} \mathrm{O}_{2}$ added during intensive cell division (early $\mathrm{H}_{2} \mathrm{O}_{2}$-treated cells), none of the tested cytochrome pathway properties changed significantly except for a slight increase in the external NADH-supported uncoupled respiration (Fig. 3). These results indicate that the $48 \mathrm{~h}$ period of $\mathrm{H}_{2} \mathrm{O}_{2}$-induced stress, which was followed by $24 \mathrm{~h}$ regeneration period during which the cells underwent intensive division, led to the delay of cell growth reaching the late exponential phase instead of the stationary phase (Fig. 1). Mitochondria isolated from early $\mathrm{H}_{2} \mathrm{O}_{2}$-treated cells displayed the bioenergetic properties of mitochondria from the late exponential phase (Czarna et al. 2007), and thus, no damage to their function was observed.

In contrast to the early $\mathrm{H}_{2} \mathrm{O}_{2}$-treated cells, growth of $A$. castellanii cells in the presence of $1.4 \mathrm{mM} \mathrm{H}_{2} \mathrm{O}_{2}$ added during slowing cell division (at the intermediary phase, late $\mathrm{H}_{2} \mathrm{O}_{2}$-treated cells) was associated with marked changes in the cytochrome pathway (complex III and complex IV) activity, i.e., the $\mathrm{QH}_{2}$-oxygen oxido-reductase activity (Fig. 3). In mitochondria isolated from late $\mathrm{H}_{2} \mathrm{O}_{2}$-treated cells, the rates of uncoupled (FCCP-stimulated) respiration using either $\mathrm{NADH}$, succinate or malate as the respiratory substrate decreased significantly, and this effect was independent of the supplied respiratory substrate (Fig. 3a). Coupling parameters, i.e., respiratory control ratios (RCR) and $\mathrm{ADP} / \mathrm{O}$ values (Fig. 3b, c), as well as the membrane potential (Fig. 3e) and endogenous $Q$ reduction level (Fig. 3f) of the resting (non-phosphorylating) state were also lowered. A considerable increase (around 38\%) in the amount of membranous Q was observed (Fig. 3g). However, no differences were observed in non-phosphorylating state 4 respiration (data not shown), indicating that external
NADH dehydrogenase activity was not damaged under $\mathrm{H}_{2} \mathrm{O}_{2}$-induced stress conditions. In addition, no change in the amount of complex IV protein (Fig. 3) or in its activity (Fig. 2) was observed, indicating that the terminal oxidase of the A. castellanii respiratory chain is not rate limiting for the cytochrome pathway-sustained respiration in mitochondria from both early and late $\mathrm{H}_{2} \mathrm{O}_{2}$-treated cells. The respiratory rate with exogenous cytochrome $c$ as the respiratory substrate was not significantly different in any of the tested mitochondria, indicating that the stressinduced inhibition observed in mitochondria from late $\mathrm{H}_{2} \mathrm{O}_{2}$-treated cells occurred before the cytochrome $c$ oxidase (complex IV) step of the respiratory chain. Thus, the lower respiratory capacity of the cytochrome pathway observed in mitochondria of late $\mathrm{H}_{2} \mathrm{O}_{2}$-treated cells likely results from reduced activity of complex III.

No significant difference in the outer mitochondrial membrane integrity of $A$. castellanii mitochondria was found between mitochondria isolated from control and stressed cells. Specifically, the outer mitochondrial membrane integrity averaged $98 \pm 2 \%, 98 \pm 4 \%$, and $94 \pm 5 \%$ for mitochondria isolated from control, early and late $\mathrm{H}_{2} \mathrm{O}_{2}$-treated cells, respectively (for five different mitochondria preparations).

\section{Energy-dissipating systems: AcAOX and AcUCP}

Changes in the AcAOX-mediated respiration with NADH as the respiratory substrate were also examined via measurement of the cyanide-resistant respiration in the absence (unstimulated capacity) or in the presence of the most efficient activator of the enzyme (1 mM GMP) (stimulated capacity). A significant (at least 50\%) increase in the stimulated and unstimulated AcAOX capacity (Fig. 4a) and in the AcAOX protein level (Fig. 4c) was

Fig. 4 Energy-dissipating systems in mitochondria isolated from $A$. castellanii cultures grown in the absence (control cells) or presence of $\mathrm{H}_{2} \mathrm{O}_{2}$ (early and late $\mathrm{H}_{2} \mathrm{O}_{2}$-treated cells). a AcAOX activity was measured as cyanide-resistant respiration in the presence of $1 \mathrm{mM}$ $\mathrm{NADH}$ as the respiratory substrate, $2 \mathrm{mM}$ cyanide, $0.1 \% \mathrm{BSA}, 1 \mu \mathrm{M}$ carboxyatractyloside, $0.5 \mu \mathrm{M}$ oligomycin, plus or minus $1 \mathrm{mM}$ GMP. b AcUCP activity (linoleic acid-induced respiration) was measured in the presence of $1 \mathrm{mM}$ NADH, $2 \mathrm{mM}$ BHAM, $1 \mu \mathrm{M}$ carboxyatractyloside, $0.5 \mu \mathrm{M}$ oligomycin, and increasing LA concentrations (up to $20 \mu \mathrm{M}$ ). The reported linoleic acid-induced respiration is the difference between respiration observed in the presence of the most effective concentration of linoleic acid and the respiration measured before its addition. $\mathbf{a}$ and $\mathbf{b}$ The data shown represent five different mitochondrial preparations for the given conditions. The mean values $\pm \mathrm{SE}$ are shown $(n=6) . *, * *$ Where indicated, $p$ values are significantly different from control values $(p<$ 0.05 or $p<0.01$, respectively; Student's unpaired $t$ test). c Immunodetection of AcAOX and AcUCP proteins. The mitochondrial protein equivalent of $100 \mu \mathrm{g}$ was loaded in all lines. Examples of four immunoblots, using mitochondria from different preparations, are shown. The highest intensity band was set at "1" and other values are calculated relative to that value. Below, the results of the densitometric analysis are expressed in arbitrary units 


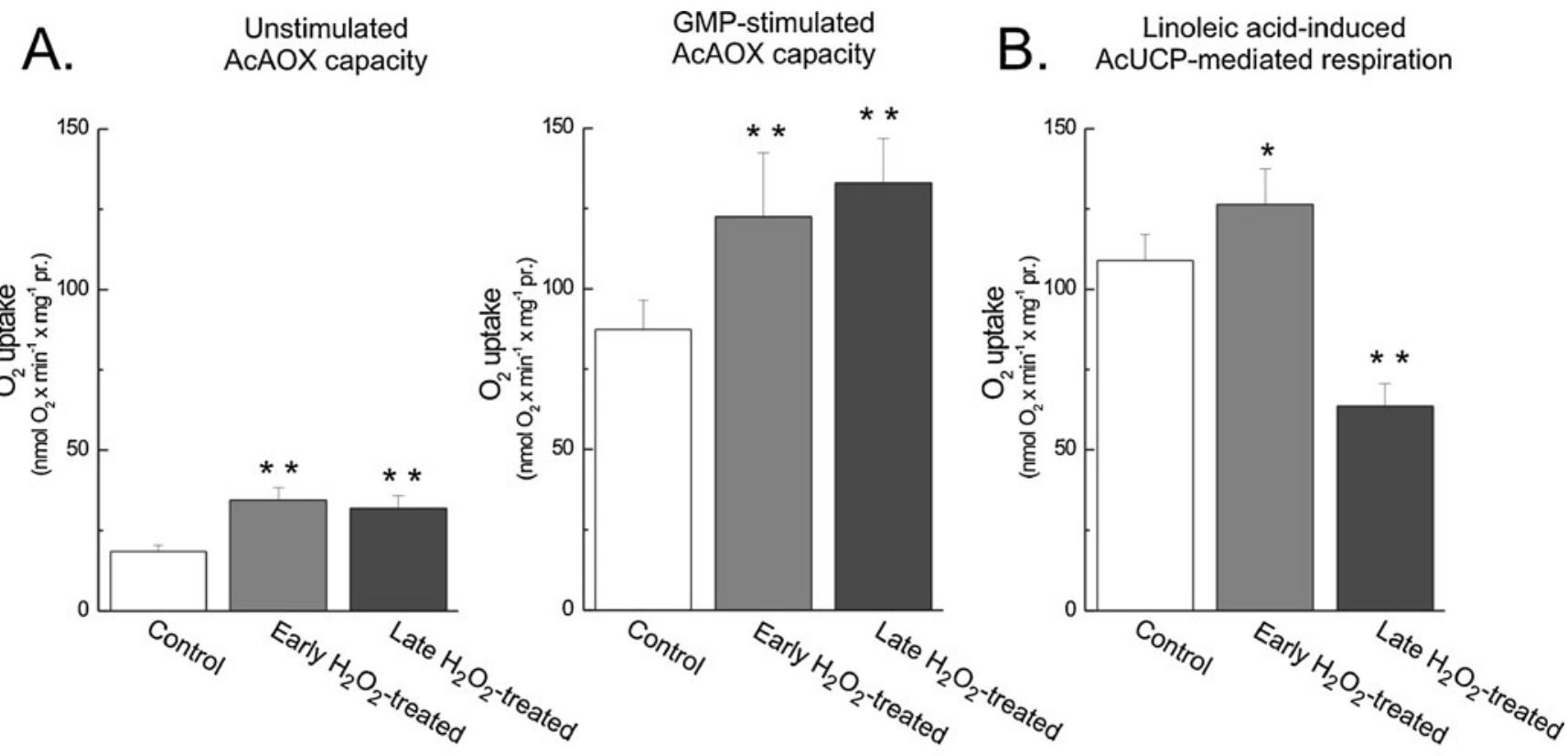

C. AcAOX

AcUCP

cox
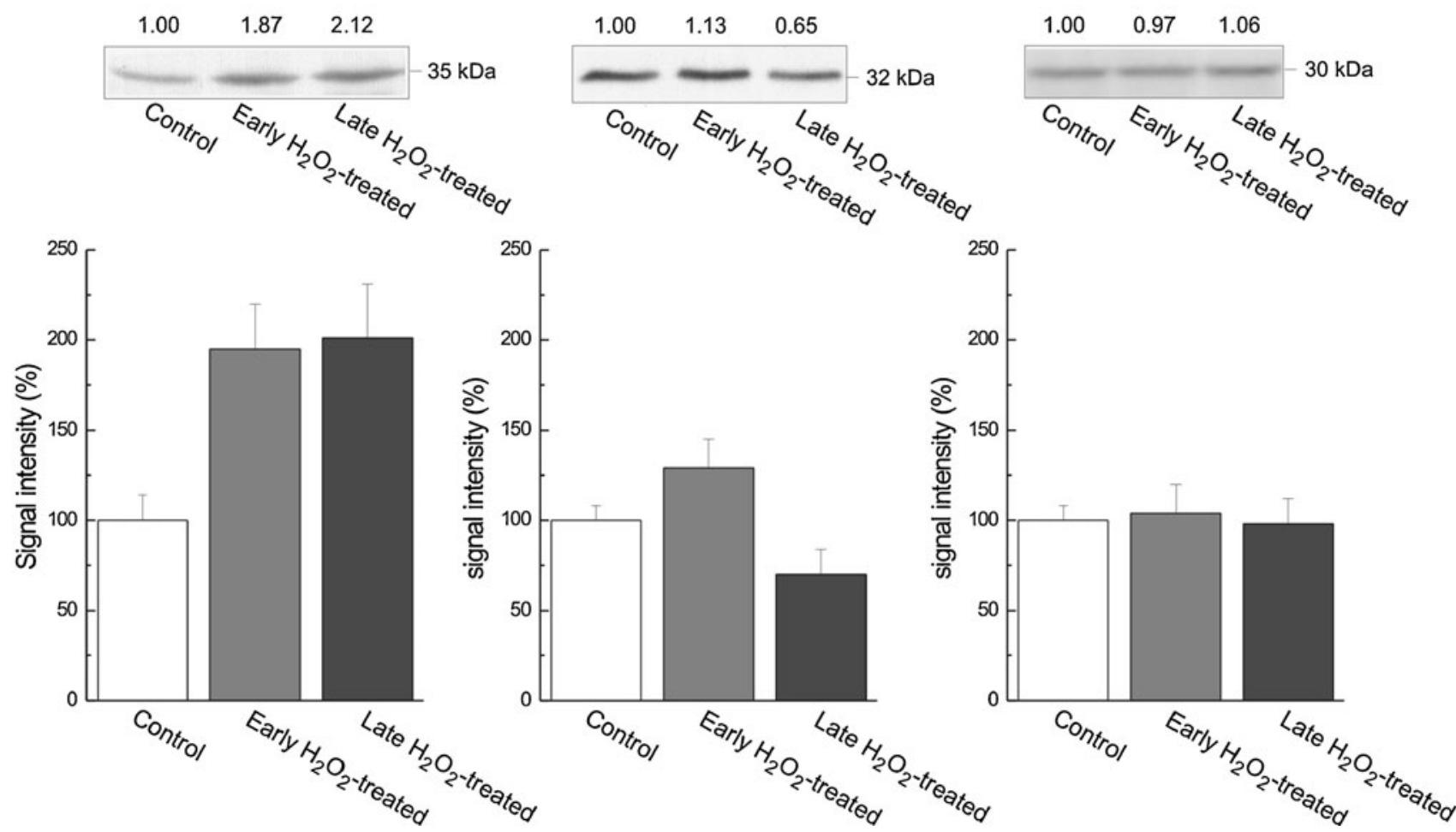

observed in mitochondria isolated from early and late $\mathrm{H}_{2} \mathrm{O}_{2}$-treated cells when compared to control mitochondria. The enhanced rate of stimulated and unstimulated cyanideresistant respiration was also observed with succinate and malate as respiratory substrates (data not shown).
Figure $4 \mathrm{a}$ shows the effect of $\mathrm{H}_{2} \mathrm{O}_{2}$ treatment of the $A$. castellanii culture on the linoleic acid-induced mitochondrial respiration that represents the AcUCP capacity. The AcUCP-sustained respiration activated by linoleic acid (maximal stimulation at $20 \mu \mathrm{M}$ ) was measured in state 4 
in the presence of carboxyatractyloside to exclude ATP/ ADP antiporter and in the presence of BHAM to inhibit AcAOX. For mitochondria isolated from early $\mathrm{H}_{2} \mathrm{O}_{2}$ treated cells, i.e., when $\mathrm{H}_{2} \mathrm{O}_{2}$ was added during intensive cell division, a less pronounced, approximately $20 \%$ increase was observed in the AcUCP capacity (Fig. 4b) and protein level (Fig. 4c) compared to the AcAOX results. In contrast, for mitochondria isolated from late $\mathrm{H}_{2} \mathrm{O}_{2}$ treated cells, a significant (at least 30\%) decline in the linoleic acid-induced AcUCP-sustained respiration (Fig. 4b) and AcUCP protein level (Fig. 4c) was observed when compared to control mitochondria isolated from untreated cells.

In the $A$. castellanii mitochondria isolated from cultures grown in the presence of $\mathrm{H}_{2} \mathrm{O}_{2}$ added during intensive cell division (early $\mathrm{H}_{2} \mathrm{O}_{2}$-treated cells), concomitant increases in the activity and protein levels of both energy-dissipating systems (AcAOX and AcUCP) are consistent with our interpretation that these cells are counterparts of control cells from late exponential phase and that these cells display bioenergetic properties of their mitochondria. When $A$. castellanii cells shift from the exponential phase to the stationary phase, a decrease in the activity and protein level of AcAOX and AcUCP has previously been observed (Czarna et al. 2007).

\section{Discussion}

The addition of a moderate $(1.4 \mathrm{mM})$ concentration of $\mathrm{H}_{2} \mathrm{O}_{2}$ to A. castellanii batch cultures at different phases of growth, i.e., during intensive cell division (early $\mathrm{H}_{2} \mathrm{O}_{2}$ treated cells) and during slowing cell division approaching the stationary phase preceding encystment (late $\mathrm{H}_{2} \mathrm{O}_{2}$ treated cells), caused a different response to oxidative stress. In the former case, the addition of $\mathrm{H}_{2} \mathrm{O}_{2}$ to exponentially growing cells significantly delayed growth of the A. castellanii batch culture, and after approximately $48 \mathrm{~h}$, these cells restarted intensive division and reached a density of a late exponential phase instead of a stationary phase as observed in untreated control cells. Moreover, mitochondria isolated from early $\mathrm{H}_{2} \mathrm{O}_{2}$-treated cells revealed an increased activity of the energy-conserving (cytochrome pathway) and energy-dissipating (AcUCP and AcAOX) systems; they exhibited bioenergetic properties of the mitochondria from the late exponential phase (Czarna et al. 2007). Therefore, the $24 \mathrm{~h}$ regeneration period during which the cells underwent intensive division allowed the cells to overcome $\mathrm{H}_{2} \mathrm{O}_{2}$-induced oxidative stress. In mitochondria isolated from early $\mathrm{H}_{2} \mathrm{O}_{2}$-treated cells, no damage to their bioenergetic function and either no increase or a slight increase in oxidized proteins was observed.
In contrast to early $\mathrm{H}_{2} \mathrm{O}_{2}$-treated cells, addition of $\mathrm{H}_{2} \mathrm{O}_{2}$ to $A$. castellanii cells during slowing cell division (at the intermediary phase) did not considerably influence the growth conditions of the batch culture while seriously affecting mitochondrial bioenergetic function. Treated cells remained viable and maintained mitochondrial integrity. In late $\mathrm{H}_{2} \mathrm{O}_{2}$-treated cells, oxidative damage was revealed by significantly elevated levels of oxidized protein in the mitochondria. Moreover, in mitochondria isolated from these cells, the cytochrome pathway activity (uncoupled respiration), the efficiency of oxidative phosphorylation (ADP/O ratio), the membrane potential and the endogenous $\mathrm{Q}$ reduction level of the resting state were lowered. These results indicate that the components of the main mitochondrial respiratory pathway and likely ATP synthase in $A$. castellanii were damaged under $\mathrm{H}_{2} \mathrm{O}_{2}$-induced oxidative stress conditions. Similar results were observed in the mitochondria of plants treated with elevated $\mathrm{H}_{2} \mathrm{O}_{2}$ concentrations. Treatment of Arabidopsis cell cultures with $88 \mathrm{mM}$ $\mathrm{H}_{2} \mathrm{O}_{2}$ for 7 days resulted in the degradation of the tricarboxylic acid cycle and some respiratory chain proteins as well as subunits of ATP synthase; these changes led to a decrease in respiration, but mitochondrial integrity was maintained (Sweetlove et al. 2002). In A. castellanii mitochondria from late $\mathrm{H}_{2} \mathrm{O}_{2}$-treated cells, an increase in the amount of membranous $\mathrm{Q}$ could allow a decreased $\mathrm{Q}$ pool reduction level (at a given influx of reducing substrates to the mitochondria) and consequently reduce production of harmful ROS. For the first time, this study has shown that the regulation of $\mathrm{Q}$ content in the inner mitochondrial membrane can play a role in the response to oxidative stress.

Because the action of AcUCP is driven by the membrane potential, which depends on the cytochrome pathway activity (Jarmuszkiewicz et al. 1999), it is not surprising that a significant decline either in the AcUCP activity and protein level was observed in mitochondria isolated from late $\mathrm{H}_{2} \mathrm{O}_{2}$ treated cells. Moreover, an increase in the amount of membranous $\mathrm{Q}$ and consequently a decrease in the $\mathrm{Q}$ reduction level (at a given influx of reducing substrates to the mitochondria) observed in the mitochondria from late $\mathrm{H}_{2} \mathrm{O}_{2}$-treated cells indicate that there is a low engagement of the present AcUCP. As shown previously, the inhibition efficiency of purine nucleotides for AcUCP-sustained uncoupling in A. castellanii mitochondria depends on the endogenous Q redox state, specifically on ubiquinol $\left(\mathrm{QH}_{2}\right)$ content (Jarmuszkiewicz et al. 2005b; Swida et al. 2008; WoydaPloszczyca and Jarmuszkiewicz 2011). Thus, in A. castellanii cells with a damaged mitochondrial cytochrome pathway, AcUCP is not involved in antioxidant defense as a response protein to oxidative stress.

In late A. castellanii $\mathrm{H}_{2} \mathrm{O}_{2}$-treated cells, $\mathrm{H}_{2} \mathrm{O}_{2}$-induced oxidative stress led to reduced respiratory capacity of the main cytochrome pathway but not the ubiquinol alternative 
pathway (AcAOX), which was up-regulated and exhibited increased protein amounts and activity. This result is consistent with an attempt by the A. castellanii cells to maintain total respiratory capacity of the mitochondria in stressed cells compared to control cells. In contrast, in $\mathrm{H}_{2} \mathrm{O}_{2}$-treated Arabidopsis cells, oxidative stress reduces the mitochondrial respiratory capacity through both the cytochrome and AOX pathways, primarily by inhibiting electron flow through the respiratory dehydrogenases into the $\mathrm{Q}$ pool rather than by inhibiting the activity of respiratory oxidases (Sweetlove et al. 2002). Conversely, in A. castellanii mitochondria from late $\mathrm{H}_{2} \mathrm{O}_{2}$-treated cells, the rate of cyanide-resistant respiration (unstimulated and GMP-stimulated) was higher than that in mitochondria from control cells, and this effect was independent of the respiratory substrate used,. Unaffected respiratory dehydrogenase activities (at least the external NADH dehydrogenase activity) at concomitant lowered cytochrome pathway capacity establish conditions that cause increased demand for alternative pathway (AcAOX) activity. Our results indicate that in unicellular organisms, such as A. castellanii, AOX acts as a response protein to oxidative stress that allows increased mitochondrial oxygen consumption that could lead to some improvement in biosynthesis and growth under conditions of oxidative damage caused by $\mathrm{H}_{2} \mathrm{O}_{2}$. Increased AcAOX activity during oxidative stress could diminish the increase in reducing power, thus providing $\mathrm{NAD}^{+}$to the Krebs cycle and glycolysis and consequently providing carbon skeletons for biosynthesis. Furthermore, the increased AcAOX activity, which is accompanied by increased protein levels, would attempt to maintain the rate of mitochondrial electron transport to oxygen, compensating for the higher sensitivity of the cytochrome pathway to oxidative damage and thereby preventing production of harmful oxygen species. In $A$. castellanii mitochondria, AcAOX could also be directly involved in antioxidant defense because its activation lowers ROS formation (Czarna and Jarmuszkiewicz 2005). Protection against mitochondrial oxidative stress, involving maintenance of the balance of cell energy metabolism and the limitation of mitochondrial ROS production, may be a physiological role of AOX in unicellular organisms, especially when the secondary mitochondrial energy-dissipating systems (UCP) cannot work.

Acknowledgements This work was supported by a grant from the Polish Ministry of Education and Science (0505/B/P01/2009/36). We thank Jaroslaw Haremza and Wojciech Michalak for their technical assistance.
Open Access This article is distributed under the terms of the Creative Commons Attribution Noncommercial License which permits any noncommercial use, distribution, and reproduction in any medium, provided the original author(s) and source are credited.

\section{References}

Czarna M, Jarmuszkiewicz W (2005) FEBS Lett 579:3136-3140

Czarna M, Sluse FE, Jarmuszkiewicz W (2007) J Bioenerg Biomembranes 39:149-157

Jarmuszkiewicz W, Wagner AM, Wagner MJ, Hryniewiecka L (1997) FEBS Lett 411:110-114

Jarmuszkiewicz W, Sluse-Goffart CM, Hryniewiecka L, Michejda J, Sluse FE (1998) J Biol Chem 273:10174-10180

Jarmuszkiewicz W, Sluse-Goffart CM, Hryniewiecka L, Sluse FE (1999) J Biol Chem 274(33):23198-23202

Jarmuszkiewicz W, Frączyk O, Hryniewiecka L (2001) Acta Biochim Pol 48:729-737

Jarmuszkiewicz W, Sluse FE, Hryniewiecka L, Sluse-Goffart CM (2002) J Bioenerg Biomembr 34:31-40

Jarmuszkiewicz W, Antos N, Swida A, Czarna M, Sluse FE (2004) FEBS Lett 569:178-184

Jarmuszkiewicz W, Czarna M, Sluse FE (2005a) Biochim Biophys Acta 1708(1):71-78

Jarmuszkiewicz W, Swida A, Czarna M, Antos N, Sluse-Goffart CM, Sluse FE (2005b) J Bioenerg Biomembranes 37(2):97-107

Jarmuszkiewicz W, Antos-Krzeminska N, Drachal-Chrul D, Matkovic K, Nobik W, Pieńkowska J, Swida A, Woyda-Ploszczyca AM, Budzinska M (2008) Acta Biochim Pol 55:349-355

Jarmuszkiewicz W, Woyda-Ploszczyca AM, Krzeminska N, Sluse FE (2010) Biochim Biophys Acta 1797:792-799

Kamo N, Muratsugu M, Hongoh R, Kobatake Y (1979) J Membr Biol 49:105-121

Kicinska A, Swida A, Bednarczyk P, Koszela-Piotrowska I, Choma K, Dolowy K, Szewczyk A, Jarmuszkiewicz W (2007) J Biol Chem 282:17433-17441

Papa S, Skulachev VP (1997) Mol Cell Biochem 174:305-319

Popov VN (2003) Biochem Soc Trans 31(6):13-16

Radi R, Bush KM, Freeman BA (1993) Arch Biochem Biophys 300:409-415

Sweetlove LJ, Heazlewood JL, Herald V, Holtzapffel R, Day DA, Leaver CJ, Millar AH (2002) Plant J 32:891-904

Swida A, Czarna M, Woyda-Płoszczyca A, Kicinska A, Sluse FE, Jarmuszkiewicz W (2007) J Bioenerg Biomembr 39(1):109-115

Swida A, Woyda-Ploszczyca A, Jarmuszkiewicz W (2008) Biochem J 413:359-367

Vercesi AE, Borecky J, Maia ID, Arruda P, Cuccovia IM, Chaimovich H (2006) Annu Rev Plant Biol 57:383-404

Vladimirov YA, Olenev VI, Suslova TB, Cheremisina ZP (1980) Adv Lipid Res 17:173-249

Wainright PO, Hinkle G, Sogin ML, Stickel SK (1993) Science 260:340-342

Woyda-Ploszczyca A, Jarmuszkiewicz (2011) Biochim Biophys Acta 1807:42-52

Woyda-Ploszczyca A, Sluse FE, Jarmuszkiewicz W (2009) Biochim Biophys Acta 1787:264-271

Zhang Y, Marcillat O, Giulivi C, Ernster L, Davies KJA (1990) J Biol Chem 265(27):16330-16336 